\title{
Compiling of comprehensive data of human infections with novel influenza A (H7N9) virus
}

\author{
Ying Wu $(\bowtie)^{1, a}$, George F. Gao $(\bowtie)^{1,2, b}$ \\ ${ }^{1}$ CAS Key Laboratory of Pathogenic Microbiology and Immunology, Institute of Microbiology, Chinese Academy of Sciences, Beijing \\ 100101, China, ${ }^{2}$ Chinese Center for Disease Control and Prevention, Beijing 102206, China \\ (C) Higher Education Press and Springer-Verlag Berlin Heidelberg 2013
}

Starting from February, 2013, avian-origin influenza A (H7N9) virus infection had been prevalent in Eastern China, with a total of 133 infected cases and, among them 43 deaths as of July 4th (www.who.org), 2013. It has caused serious worrisome concerns about a possible pandemic. This virus is a new reassorted subtype of avian influenza virus to cause human disease, especially this is the first time for a lowpathogenic avian influenza virus to cause a population level infection in humans, though sporadic cases have been reported earlier. Through an international collaboration, especially the great efforts from the China side, the disease was quickly conquered after its link with the live poultry markets was confirmed [1-4]. A series of scientific reports in a variety of international journals has been made and the event has ever been well described [5-10].

In this issue of Frontiers of Medicine, Chen et al. described the first fatal H7N9 case in Hangzhou, Zhejiang Province [11]. This is the first report to compile all the data, from clinical features, epidemiology, especially live poultry market exposure connections, etiology, to diagnosis and clinical treatment, together for a comprehensive analysis. They have made some key conclusions from this case. More importantly, though the patient had some direct contacts, and two of them even showed flu-like clinical symptoms, no human-to-human transmission was confirmed as no viral RNA was detected by RT-PCR from the contact samples. Yet, they comprehensively tested over a hundred persons but no positive was observed, neither in the RT-PCR for viral RNA detection nor in the serological tests for antibodies. This again raises the suspicion of human-tohuman transmission in spite of the unavailability thus far

Correspondence: awuying@im.ac.cn; baofu@chinacdc.cn of confirmed evidence. This is the lucky part of this outbreak. Of course this yet needs to be evaluated in detail in the future.

Data sharing is crucial for our understanding and control of the emerging pathogens. One piece of the data shared in this comprehensive case report is the lessons learnt for early diagnosis and antiviral application. In this case the fatal patient had never used influenza-specific antivirals and this led to wideuse of the neuraminidase inhibitor, oseltamivir, for the patients in the later outbreak once the virus infection was confirmed. The general practice in the later stage was that any suspected patients must be given oseltamivir within 48 hours of the diagnosis. It has been concluded by now that this practice has saved lives in this outbreak and is hence recommended for any possible returned H7N9 infection in the autumn. From this point the timely publication of this work is important.

Facing the unpredictable H7N9 virus outbreak, we ought to think hard for our future. Should the infection come back, what should we do? Are we well prepared for any possible outbreak or even pandemic? The emergence of new subtype of H7N9 virus reminds us of the limitation of pre-warning or prediction of pandemic flu. Accumulation of data, both clinical and basic sets, is crucial in combating any emerging pathogens.

\section{References}

1. Chen Y, Liang W, Yang S, Wu N, Gao H, Sheng J, Yao H, Wo J, Fang Q, Cui D, Li Y, Yao X, Zhang Y, Wu H, Zheng S, Diao H, Xia S, Zhang Y, Chan KH, Tsoi HW, Teng JL, Song W, Wang P, Lau SY, Zheng M, Chan JF, To KK, Chen H, Li L, Yuen KY. Human infections with the emerging avian influenza A H7N9 virus from wet market poultry: clinical analysis and characterisation of viral genome. Lancet 2013; 381(9881): 1916-1925

2. Gao R, Cao B, Hu Y, Feng Z, Wang D, Hu W, Chen J, Jie Z, Qiu H, 
Xu K, Xu X, Lu H, Zhu W, Gao Z, Xiang N, Shen Y, He Z, Gu Y, Zhang Z, Yang Y, Zhao X, Zhou L, Li X, Zou S, Zhang Y, Li X, Yang L, Guo J, Dong J, Li Q, Dong L, Zhu Y, Bai T, Wang S, Hao P, Yang W, Zhang Y, Han J, Yu H, Li D, Gao GF, Wu G, Wang Y, Yuan Z, Shu Y. Human infection with a novel avian-origin influenza A (H7N9) virus. N Engl J Med 2013; 368(20): 1888-1897

3. Li J, Yu X, Pu X, Xie L, Sun Y, Xiao H, Wang F, Din H, Wu Y, Liu D, Zhao G, Liu J, Pan J. Environmental connections of novel avianorigin H7N9 influenza virus infection and virus adaptation to the human. Sci China Life Sci 2013; 56(6): 485-492

4. Wu Y, Gao GF. Lessons learnt from the human infections of avianorigin influenza A H7N9 virus: live free markets and human health. Sci China Life Sci 2013; 56(6): 493-494

5. Cowling BJ, Jin L, Lau EH, Liao Q, Wu P, Jiang H, Tsang TK, Zheng J, Fang VJ, Chang Z, Ni MY, Zhang Q, Ip DK, Yu J, Li Y, Wang L, Tu W, Meng L, Wu JT, Luo H, Li Q, Shu Y, Li Z, Feng Z, Yang W, Wang Y, Leung GM, Yu H. Comparative epidemiology of human infections with avian influenza A H7N9 and H5N1 viruses in China: a population-based study of laboratory-confirmed cases. Lancet 2013 Jun 21. [Epub ahead of print] DOI: 10.1016/S01406736(13)61171-X

6. Hu Y, Lu S, Song Z, Wang W, Hao P, Li J, Zhang X, Yen HL, Shi B, Li T, Guan W, Xu L, Liu Y, Wang S, Zhang X, Tian D, Zhu Z, He J, Huang K, Chen H, Zheng L, Li X, Ping J, Kang B, Xi X, Zha L, Li Y, Zhang Z, Peiris M, Yuan Z. Association between adverse clinical outcome in human disease caused by novel influenza A H7N9 virus and sustained viral shedding and emergence of antiviral resistance.
Lancet 2013; 381(9885): 2273-2279

7. Liu D, Shi W, Shi Y, Wang D, Xiao H, Li W, Bi Y, Wu Y, Li X, Yan J, Liu W, Zhao G, Yang W, Wang Y, Ma J, Shu Y, Lei F, Gao GF. Origin and diversity of novel avian influenza A H7N9 viruses causing human infection: phylogenetic, structural, and coalescent analyses. Lancet 2013; 381(9881): 1926-1932

8. Yu H, Cowling BJ, Feng L, Lau EH, Liao Q, Tsang TK, Peng Z, Wu P, Liu F, Fang VJ, Zhang H, Li M, Zeng L, Xu Z, Li Z, Luo H, Li Q, Feng Z, Cao B, Yang W, Wu JT, Wang Y, Leung GM. Human infection with avian influenza A H7N9 virus: an assessment of clinical severity. Lancet 2013 Lancet 2013 Jun 21. [Epub ahead of print] DOI: 10.1016/S0140-6736(13)61207-6

9. Zhu Y, Qi X, Cui L, Zhou M, Wang H. Human co-infection with novel avian influenza A H7N9 and influenza A H3N2 viruses in Jiangsu province, China. Lancet 2013; 381(9883): 2134

10. Li Q, Zhou L, Zhou M, Chen Z, Li F, Wu H, Xiang N, Chen E, Tang F, Wang D, Meng L, Hong Z, Tu W, Cao Y, Li L, Ding F, Liu B, Wang M, Xie R, Gao R, Li X, Bai T, Zou S, He J, Hu J, Xu Y, Chai C, Wang S, Gao Y, Jin L, Zhang Y, Luo H, Yu H, Gao L, Pang X, Liu G, Shu Y, Yang W, Uyeki TM, Wang Y, Wu F, Feng Z. Preliminary Report: Epidemiology of the Avian Influenza A (H7N9) Outbreak in China. N Engl J Med 2013 Apr 24. [Epub ahead of print] DOI: 10.1056/NEJMoa1304617

11. Chen E, Wang F, Lv H, Zhang Y, Ding H, Liu S, Cai J, Xie L, Xu X, Chai C, Mao H, Sun J, Lin J, Yu Z, Li L, Chen Z, Xia S. The first avian influenza A (H7N9) viral infection in humans in Zhejiang Province, China: a death report. Front Med 2013; 7(3): 333-344 